\title{
1. What was the contribution of the medieval civilians?
}

One way to understand legal knowledge and reasoning is to ask what legal knowledge and reasoning has been. In this chapter and the two that follow this will be the guiding question; for no rethinking of the subject can possibly be undertaken without consideration of law's rich history, especially as this history might well be described as one of changing methods and theories. Having posed the 'what has legal reasoning been' question, the next issue is where to start. As a discipline the historical starting point of law and legal reasoning is to be found in the Ancient World, particularly Rome. The obvious temptation is therefore to begin with the Roman jurists. Yet this might not be the most insightful approach. It might instead be more helpful to begin with the medieval Italian jurists who studied the rediscovered Roman texts in the eleventh century and worked on them over the next four centuries. It is these jurists who not just acted as the intermediary between the original Roman law and contemporary systems but developed and consolidated many methods that are still used today. Having studied these medieval jurists one can then look backwards to Roman law itself and then forwards to the centuries that followed the end of the medieval world.

\subsection{GENERAL REMARKS}

If one is to attempt to discover the 'attitude' referred to by Dworkin where should one start? If one were to look at legal reasoning in terms of time the point of departure would no doubt be the Roman jurists. ${ }^{1}$ This, indeed, is where James Gordley starts in his historical work on the jurists. ${ }^{2}$ But Véronique Champeil-Desplats, in her book on legal science and method, is slightly more nuanced in as much as she could be seen as taking the Renaissance as her reference point. ${ }^{3}$ And such an approach is

\footnotetext{
Stein (1999).

Gordley (2013).

3 Champeil-Desplats (2016), at 50.
} 
possibly more helpful if one wishes to understand contemporary reasoning methods since - and Gordley equally emphasises this point - it is the rationalists that laid the foundations for a conceptualist and formalist approach to legal thought and method. 'Indeed', says Gordley, 'it became the project of the twentieth-century jurists to expose [the] failure, and to find an alternative to positivism and conceptualism.' ${ }^{4}$

Yet neither the period of Roman lawyers nor that of the Renaissance is necessarily the best point of departure for an understanding of legal reasoning. Arguably, it might be more useful to locate this starting point a little earlier; one might start with the medieval jurists who worked, from the eleventh to the fifteenth century in Italy and elsewhere, on the rediscovered Roman texts that had been compiled and preserved by the Emperor Justinian in the sixth century AD. 'Even today', wrote Walter Jones in his history of legal theory, 'so many roads in law lead us back to Rome by way of the Commentators on the Roman law. ${ }^{5}$ In order to discover what legal reasoning has been, and to relate this diachronic account with the present, one might start with those jurists who, so it might be argued, are pivotal in orientating an analysis that links the diachronic with the synchronic. One might start at a half-way point from where one can look both backwards to the Roman jurists and forwards to the subsequent civilians and common lawyers.

When the Roman sources were rediscovered in the eleventh century the medieval university teachers evidently found a body of texts which were exceptionally rich in their intellectual promise. ${ }^{6}$ Here was a complete book (or books) of materials that contained not just a mass of positive law so to speak but also a sophisticated selection of reasoning techniques encompassed within a described philosophical and epistemological theory. ${ }^{7}$ These Roman materials (Libri legales) - which subsequently were given the name Corpus Iuris Civilis - acted as the textual foundation for teaching of law first in Italy, in particular at Bologna, and then elsewhere in Europe. ${ }^{8}$ This rediscovery and the medieval scholarship that it attracted has been described as nothing short of revolutionary; the medieval jurists 'gave the West its characteristic

4 Gordley (2013), at 215.

5 Jones (1940), at x (Preface). The Commentators, or Post-Glossators, were late medieval jurists.

6 See generally Berman (1983).

Jones (1940), at 3-11.

8 Gordley (2013), at 28-32. 
methods of analysis and synthesis of texts' and these methods are 'still [those] of legal science in the United States today'. ${ }^{9}$

\subsection{GLOSSATORS}

The eleventh century intellectual revival did not just concern Roman law, but in Italy centres of legal learning developed, the most important of which was in Bologna under the guidance of a teacher called Irnerius (1055-1125?) sometimes known as lucerna iuris. This teacher had the courage (for the material cannot have been easily comprehensible to the medieval mind) to study the Roman compilation in its original version and not through other works which had distorted the original Roman texts. ${ }^{10}$ In truth Irnerius was not trained as a lawyer; he was a specialist in the liberal arts whose interest in law was awakened when he came across legal texts. ${ }^{11} \mathrm{He}$ started to examine these texts and to explain and cross-reference the various terms used. Moreover, as will be seen, he initiated a particular mental attitude towards the Roman texts; they assumed a status of complete authority and in turn this fed back into the methods that these jurists brought to bear on the texts. The material was to be studied with the aim not only to be understood - a process that involved having to harmonise apparently discordant texts - but to be gradually adapted to the problems of the world in which the Glossators lived.

Irnerius had four pupils - Bulgarus, Martinus, Hugo and Jacobus who were to continue his work after his death. ${ }^{12}$ These four were of considerable influence with regard not just to legal scholarship but also to practical politics when they acted as advisors to princes and administrators. The importance of these successors is that they developed interpretative methods through the use of distinctions on the one hand and analogy (ad similia) on the other. ${ }^{13}$ After the four doctors came Vacarious (c.1120-c.1200), who may have taught Roman law in England. ${ }^{14}$ And then in the late twelfth and early thirteenth centuries, Azo (c.1150-1230),

\footnotetext{
9 Berman (1983). See also Brundage (2008), at 76-80.

Maruotti (2011), at 95.

Ibid, at 93.

De Zulueta and Stein (1990), at xvi.

13 Maruotti (2011), at 100; De Zulueta and Stein (1990), at xv.

14 See generally De Zulueta and Stein (1990).
} 
who published a major treatise on the code called Summa codicis (1210) and whose work was not only in use until the sixteenth century but also is said to have influenced the early English jurist Bracton (c.1210c.1268). ${ }^{15}$ Finally in the thirteenth century a jurist called Accursius (c.1182-c.1260) produced a work around 1240 (Glossae ordinariae) that summed up all the work of his predecessors. It is this work ('the Gloss') which formed the basic foundation - or starting point - for what became known as the ius commune. ${ }^{16}$

However, this definitive work also began to bring to a close this school of jurists whose name - the Glossators - is derived from the methods they employed. ${ }^{17}$ The approach owed its origin to the teaching methods to be found in the medieval university. The technique used by Irnerius and his successors involved 'glossing' the Roman law texts in the margins, or between the lines, with brief explanations of the text. Their methods were scholastic (dialectical), which was designed not just as an early form of analysis but as a means of reconciling difficult problems of contradiction within the texts themselves. They employed methods actually developed by the Roman jurists such as the distinctio (genus and species) and then went on to develop others. ${ }^{18}$ These were summa (exposition and summaries on the content), casus (concrete cases), lectura (grammatical explanation of the text), brocardum (formulation of a general rule) and quaestio (questions arising out of a general rule as applied to concrete examples or questions arising out of contradictory texts). Irnerius himself seemed to have written mainly glosses commenting on the texts, but his successors went further and started to gather together collections into one book (summae) and to cross-reference different Roman texts on the same subject matter. ${ }^{19}$ A new method arising out of scholasticism was dialectica which developed out of questiones; this involved putting two contradictory texts side by side so that they could be harmonised through analysis (distinctio) and synthesis (brocardum for example) arriving at a solutio. ${ }^{20}$ 


\section{EXTRACT 1.1}

Digest 12.118 (Ulpian): If I (si ego) have given you money as if for a gift and you take it as if for a loan Julian writes that there is no gift. But let us see if there is a loan. I consider that there is no loan either. Furthermore the money does not become the property (non fieri) of the person who took it as he took the money under an impression that was different from mine. Therefore if he has spent the money and the condictio action is quite legally brought, he can all the same plead the exceptio doli [defence of fraud] because the money was spent in accordance with the will of the giver.

Gloss on D.12.1.18: 'Si ergo'. You asked me for a loan: I gave you money not as a loan but as a gift: you believed you were bound to me under a contract of loan. Will it be a gift or a loan? It will be neither a gift nor a loan: but if it is spent it will be money loaned: but the exceptio donationis will prevent me from suing, for of course what money I willingly and intended to be consumed is not to be claimed back. The same in the case which follows but where the claim is not blocked by the exceptio petendi: as in the case of a greater amount being spent and the spending will re-establish the loan. VIVIANUS. 'Non fieri'. In contrast it seems transfer of ownership did take place because we agreed on the specific thing and ownership passed; we disagreed as to the legal ground: such is D.41.1.36 which contradicts. Solution: this was a clear legal ground (certa causa), it was the sole intention that ownership be transferred, that is to say a gift; not some other ground (causa) was intended to pass ownership in the thing. There was equally the intention to accept ownership. In other words where there is a promise of a gift or obligation preceding the conveyance just a legal one is necessary for the gift to be conveyed, and you in truth accepted the credit; yet it is still your property where the gift is understood as being a future one, this is to say where mistakes vitiate the contract: see D.18.1.9.

There were a number of reasons for the success of the law school at Bologna, not the least being the support it received from the Holy Roman Emperors whose administrative centres required officials trained in Roman law and in scholastic methodology. Another reason was the sheer size of their intellectual project. To 'appraise the glossators' achievements', wrote Walter Ullmann, 'we should recall that there had been no scholarly exposition of the vast Corpus before them and that they alone and without any model had to chart a path through the labyrinth of one of the most mature legal works that had been produced in Europe'. ${ }^{21}$ They were rigorous scholars whose references were exact and whose methods in isolating a closed independent body of legal knowledge from which all excision of all non-legal material permitted them, from the mid-eleventh

21 Ullmann (1975), at 99. 
century onwards, to reason using syllogistic logic (logica nova) in solving quaestiones de facto. ${ }^{22}$ This was the basis of the modi arguendi in iure that became the means of adapting the limited case examples to be found in the Roman sources to the infinite variety of new situations occurring in medieval Europe. A third reason is that Bologna attracted thousands of students from all over Europe and this in turn was to stimulate the creation of other urban law centres in Europe.

\subsection{METHODS OF THE GLOSSATORS}

In order to appreciate the reasoning methods of the first school of medieval jurists - the Glossators ${ }^{23}$ - who worked on these Roman materials, several background epistemological factors need to be borne in mind. The first is that in this societas Christiana age texts, particularly ancient ones, had an absolute and timeless authority. ${ }^{24}$ The Digest and the Institutes were not therefore regarded as old Roman books on law but as statements of a law which were as valid in the twelfth and thirteenth centuries as in the sixth. Moreover, Justinian being a Christian Emperor, the law as laid down in the old texts had the ultimate authority of God. This auctoritas was to provide an epistemologically solid base - a locus $a b$ auctoritate - for dialectical arguments, particularly in the public debates concerning difficult quaestiones. In other words there was an 'authority paradigm' orientation that attached to the Roman (and canon law) texts which in turn furnished a rational foundation for arguments framed within a syllogistic procedure.

Secondly, Justinian had stated in the preface to the Digest (Constitutio Tanta) that no contradictions would be found in the work and that none would be found by any reader who reflected carefully on the texts; some subtle difference will always emerge that will remove an apparent inconsistency. ${ }^{25}$ This assertion by Justinian was more one of hope than reality given the speed in which the Digest was compiled. Yet the epistemological point to emphasise is that the medieval jurists took Justinian's statement as completely authoritative. Because there were contradictions in the texts, they needed therefore to develop a method that would reflect Justinian's assertion. This method was the process of

22 See generally Errera (2006). This syllogistic method was the result of the rediscovery, translation and circulation around Europe of the works of Aristotle.

23 Stein (1999), at 45-49. See also Brundage (2008), at 80-94.

24 Stein (1999), at 46.

25 Constitutio Tanta 15. 
divisio and distinctio; the more something (res) could be divided up into distinctions, sub-distinctions and sub-sub-distinctions the more one would be able to comprehend this res (quanto magis res omnis distinguitur, tanto melius aperitur, said one glossator). ${ }^{26}$

Thirdly, the Glossators regarded the Roman law as a closed body of knowledge. That is to say 'a jurist did not reason outside the orbit of the common law ("Non licet allegare nisi Iustiani leges")'; ${ }^{27}$ or, as one of the most famous Glossators put it, omnia in corpore iuris inveniuntur (everything is to be found in the body of law). ${ }^{28}$ In short, the Glossators 'viewed Justinian's codification as sufficient in itself to solve all legal problems' ${ }^{29}$ This of course presented these jurists with a methodological challenge in that there were endless factual situations occurring in the twelfth and thirteenth centuries for which there were no direct precedents in the Roman materials. How they overcame this challenge is perhaps one of the keys to understanding legal method and reasoning both then and today.

These three factors might therefore appear to place quite severe limits on the scholarship of Roman law. However, as Walter Ullmann observed, it actually created a juristic school 'distinguished by a refreshing clarity of thought, severe scholarship, exact references to sources, attention to minute detail, linguistic and dogmatic exegesis, [and] excision of all non-jurisprudential material or considerations' ${ }^{30}$ No doubt the medieval jurists were, in terms of legal reasoning and argumentation, picking up a disciplinary tradition which had ceased with the disappearance of the Roman lawyers in that they continued to reason from cases (casus) and thus, just like the old classical jurists, their methods were casuistic (cf 10.5). They remained close to the facts and extracted their solutions from these facts ('ex facto ius oritur' as one medieval Commentator put it). ${ }^{31}$ The reasoning, in other words, remained taxonomical and analogical in that facts were strictly categorised and solutions, even if they could be summed up in a general regula, would not normally extend beyond the

\footnotetext{
26 See Errera (2006), at 24-25.

27 As the jurist Azo is reported to have said to his student: Errera (2006), at 53. See also Bellomo (1995), at 144.

28 The comment is from Accursius on D.1.1.10; see De Zulueta and Stein (1990), at xiv; and Errera (2006), at 46.

29 Dondorp and Schrage, at 30.

30 Ullmann (1975), at 99.

31 See Villey (2006), at 375. The comment comes from the medieval jurist Baldus on D.9.2.52.2 in Inprimam Digesti veteris partem commentaria (although the expression was used by other Post-Glossators as well).
} 
category in which it was formulated. ${ }^{32}$ The medieval jurists, like the Roman lawyers (as will be seen), reasoned by pushing outwards from one factual situation to another. As Gordley explains, the medieval jurists were often confronted with legal problems that had no parallel at the time the Roman texts were written and thus 'they had to cite texts that had nothing to do with the problems they addressed'. ${ }^{33}$ One way of doing this was to generalise one text so as to make it applicable, later through the use of syllogistic logic based on principia (logica nova), to another situation; another way was to reason from a situation in one of the source texts and apply it by way of analogy (argumentum a simili) to the problem in hand. ${ }^{34}$ Induction and analogy thus permitted the jurist to 'move up, down, or sideways'. 35

As we shall see, this inductive and analogical method seems quite close to the techniques of the Roman jurists themselves. ${ }^{36}$ However, there are several important differences between the reasoning methods of the Roman and the medieval lawyers which must be mentioned at once. The first, and to some extent most important, was a change of object. The Romans had reasoned from texts to factual situations, but these factual situations were of as much importance to the Romans as a source of law as any statutory text, for the law to them was a living one in which the facts of cases were being generated by the very world in which they lived and breathed. One can feel this in the terms they employed: in causa ius esse positum said one jurist when discussing a complex factual problem. ${ }^{37}$ The Glossators, in contrast, took as their primary object of legal knowledge the Roman rediscovered texts which, as has been said, were regarded as having an absolute authority. The Roman jurist, says Gordley, 'began with a concept and the medieval jurist with a text'. However, Gordley goes on to make a fundamental point about the medieval (and Roman) jurists: "they both moved to their conclusions without pretending that only one solution was logically possible and without explaining why one conclusion was more appropriate than another' ${ }^{38}$

32 Thomas (2011), at 209.

33 Gordley (2013), at 32.

34 Ibid, at 33.

35 Ibid.

36 Induction and analogy are of course standard legal techniques in use today: Champeil-Desplats (2016), at 366-369.

37 D.9.2.52.2. See Samuel (2016a), at 5-6 for the full text.

38 Gordley (2013), at 35. 


\section{EXTRACT 1.2}

\section{F De Zulueta and P Stein, The Teaching of Roman Law in England Around 1200, Seldon Society, 1990, p. xv (footnotes omitted)}

Distinctiones were a series of classifications, in which particular fact-situations or legal institutions were divided and sub-divided, sometimes with the help of diagrammatic tables. Individual distinctiones of course appear in other types of literature but there were collections consisting exclusively of them. A controversial topic might be the subject of a quaestio disputata, a kind of moot-court debate, in which each side presented its argument, with supporting authorities, and then the master gave his solutio. Such debates would come naturally to those trained in the arts of dialectic, and collections of quaestiones were popular. Dissensiones dominorum were different in that they were collections of opposing glossatorial views on particular legal points, with the authorities relied on by each but without a definitive solutio.

(See also extract from Walter Ullmann: Samuel (2016a), at 10.)

The reasoning methods of the Glossators were thus orientated both towards explaining these very old materials (from almost literally a different world) and, because they took Justinian at his word with respect to the absence of contradictions, towards resolving the very real contradictions that were to be found in the Digest. ${ }^{39}$ Accordingly, a second reasoning difference was the very formal employment of dialectical reasoning. 'The technique of presenting authorities pro and contra and then trying to reconcile them', noted Peter Stein, 'was fundamental to the whole approach to the texts adopted by both civil lawyers and canonists at Bologna.' ${ }^{40}$ Now the elements of this dialectical method are to be found in the writings of the ancient Greek philosophers ${ }^{41}$ and in the reasoning of the Roman jurists. ${ }^{42}$ But the medieval philosophers and jurists developed this scheme of analysis into a very much more formal technique. This technique found expression both in the emphasis on antithetic concepts, or terminological opposite pairs, such as public versus private, actio in rem versus actio in personam, ius commune

39 See eg the apparent contradiction between D.41.1.36 and D.12.1.18 which the Gloss tried to resolve.

40 Stein (1966), at 132.

41 See eg Riffard (2013), at 47, 49, 107-108.

42 For example the view of one jurist might be stated (pro) and then the view of an opposing jurist might be added (contra): see eg D.2.4.8.2. See also D.9.2.11pr. 
versus ius proprium and so $\mathrm{on}^{43}$ and in the formal procedure of the quaestio disputata. This latter method involved the confrontation of textual passages or other disputed issues through a formal debate in which the arguments pro and contra would be advanced and a solutio reached via the use of distinction and synthesis (and see Extract 1.1 above). ${ }^{44}$ The process of moving from the arguments to the solution itself involved the analysis of a text or an object by the deployment of dialectical distinctions until such a point where descending categories of differences permitted the reconciliation of an apparent antimony.

The Glossators also benefitted from the rediscovery of the works of Aristotle on logic which began to be disseminated in Latin translation from the middle of the twelfth century. These translations were important because the Greek language presented problems for many jurists of this period (graecum est, legi non potest) ${ }^{45}$ The importance of Aristotle's works on logic lay in the fact that this philosopher was providing a method - the syllogism - by which one could infer solutions from a form of reasoning that was both rational and authoritative. What was true at the generic level ('all men are mortal') must equally be true at the specific level ('Socrates is mortal'). Consequently the combination of the taxonomical work on identity and difference (distinctio and divisio) within a structure of genus and species (inherited from the Roman jurists) with a form of reasoning that permitted this structure to be used for solving actual factual problems (which often had no direct precedent in the Roman sources) must have seemed an enormous epistemological development. Provided one could show that there was a common term between the major and minor premises it would seem that any conclusion must necessarily be true. ${ }^{46}$

\subsection{POST-GLOSSATORS (COMMENTATORS)}

The Glossators were gradually succeeded in the late thirteenth century by another school which the nineteenth century German jurist Savigny (who wrote a major work on the medieval Roman lawyers) labelled the 'Post-Glossators'. However, during the twentieth century, as their work received greater attention and appreciation, they became known as the 'Commentators' because they began to write commentaries independent

\footnotetext{
43 Carbasse (1998), at 160-161.

44 Riffard (2013), at 118-119.

45 Errera (2006), at 33.

46 Ibid, at 41.
} 
from the Roman texts themselves. It would not be strictly accurate to say that the school of Glossators came to an end with the Accursian Gloss in the first half of the thirteenth century, but their attitude and their methods had reached a point that tended towards stagnation rather than creativity. ${ }^{47}$ They focussed primarily on the Corpus of Roman law and this was not the law that was actually in force anywhere in Europe. Moreover, by the time of Accursius (1182-1260), the original Roman texts themselves had become lost behind the huge mass of often conflicting glosses. Indeed these texts had been abandoned for the Gloss (Quidquid non agnoscit glossa nec agnoscit curia, was a popular saying of the time). ${ }^{48}$

In addition, during this century, law schools had spread beyond the Alps. A school of French writers (the Ultramontani) were introducing philosophical concepts into legal writing and were displaying a freer rein in their commentaries. ${ }^{49}$ Jacobus de Ravanis (1210-1296) and Petrus de Bellapertica (died 1308) were two leading names associated with the Universities of Toulouse and Orléans. They continued to apply to the Corpus dialectical methodology but in ways that did not slavishly follow either the order of the Roman texts themselves or the Italian Glosses (they thus broke with the idea of veritas est in Glossis). ${ }^{50}$ Indeed the French jurists were only too ready to criticise the opinions in the Glosses when and where they did not agree with them. ${ }^{51}$ They freed themselves from these texts to produce more thematic and synthesised works, often rigorous thanks to the increasing sophistication of the dialectical method, itself renewed (as has been mentioned) by the rediscovery of the works of Aristotle on logic and on philosophy. ${ }^{52}$ The French writers saw the Roman texts as written reason (ratio scipta) and began to develop a far more 'scientific' (scientia iuris) logic based upon the precise definition of Roman terms which in turn were underpinned by a set of principia propria. It was in this ratio and principia where the spirit of the law was to be found: ratio est anima legis. ${ }^{53}$ The method was designed not to produce probable conclusions on the basis of legal premises that themselves were uncertain; but to produce certain and necessary results based upon premises (principia) that were certain and unopposable. The French approach found its way back to Bologna where it stimulated the new

\footnotetext{
47 Maruotti (2011), at 105-106.

48 Ibid, at 105.

49 Jones (1940), at 17-19.

50 Maruotti (2011), at 113-114.

51 Jones (1940), at 18.

52 Maruotti (2011), at 112-117.

53 Errera (2006), at 94-101.
} 
school of commentators which, subsequently, was to be dominated by two figures: Bartolus (1313-1357) and his pupil Baldus (1327-1406).

Bartolus was the most famous of the Post-Glossators (or Commentators), and for some, one of the most famous jurists ever to have lived. He studied law at Bologna and later became a professor at Perugia. His reputation was exceptional, not just in Italy, but throughout Europe and became the basis of a school of 'Bartolists' thanks to his disciples and to the methods and theories he employed (Mos Italicus). ${ }^{54}$ These methods were not invented by him since they reflected the techniques generally of the Post-Glossators, but he was a practical lawyer keen to adapt Roman law and its methods to the living law of fourteenth-century Italy. And he did this in a way that was far superior to most other jurists of his time. Indeed he became such an authority that his commentaries were a source of law in themselves (nemo jurista nisi Bartolista, was a popular saying). ${ }^{55}$ His theories about the relationship between Roman law and local customary and statutory law laid the seeds for modern private international law (conflict of law). ${ }^{56}$ His commentaries also display an acute sense of the practical and thus his writings and methods were to remain popular throughout Europe up to the seventeenth century, despite the attacks from French humanists and the rise of the natural lawyers. Moreover Bartolus made fundamental contributions to public law and political theory - indeed there 'was hardly a topic in jurisprudence that was not fructified by Bartolus' 57 - and as such he proved to be one of the first to write commentaries (in the language and concepts of law) on political problems. ${ }^{58}$ It was Bartolus who developed the notion of popular sovereignty by turning the Roman law doctrine of quod principi placuit on its head and asserting that it was the (city) state itself that was the princeps (civitas sibi princeps est). ${ }^{59}$ In short he adapted Roman law to the needs of European society and he did this by extracting from the Roman sources new principles (that is to say not ones actually formulated by the Romans themselves) that allowed Roman law to become relevant to the living law of his time.

Baldus was a student of Bartolus who became almost as famous as his master; some claim he was even better. ${ }^{60} \mathrm{He}$ taught at Perugia and Pavia,

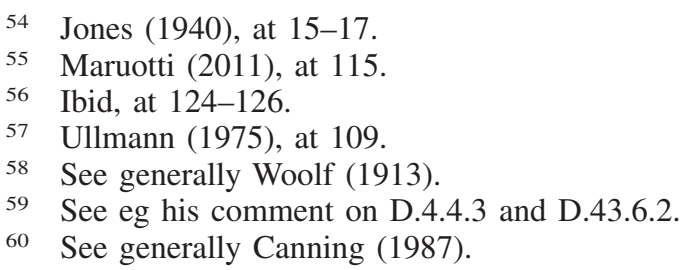


but, like Bartolus, was also famous for his practical legal opinions. Furthermore, he was much involved with the affairs of his city state, as well as advising popes and princes, and he used this experience to adapt Roman law to the political needs of the time. He was not just a Roman lawyer however; he was a specialist in canon law and feudal law and he drew on all these sources for his writings, lectures and opinions. In addition, he was learned in philosophy and this was to make him 'one of the most versatile, talented, widely read, fruitful and original thinkers in medieval jurisprudence'. ${ }^{61}$ A number of his comments have become a source of legal maxims in themselves. And his famous observation that 'law arises out of fact' (ex facto ius oritur) ${ }^{62}$ was typical of his general view of law which, for him, was an art concerned with man not nature and on cases which are 'born out of facts': nam iura ex factis nata sunt. ${ }^{63}$ This said, he also recognised that the Roman texts were more than just their words; each text was founded on a principium iuris and he who wished to know the nature of things must know their principles. ${ }^{64}$

\subsection{THEORY AND METHODS OF THE POST-GLOSSATORS}

One of the major achievements of the Post-Glossators was, via their consilia (professional opinions), to take Roman law outside the lecture hall and into society itself. This was by no means an easy exercise because the law outside the lecture hall was feudal and feudalism was quite a different conceptual and political model from the Roman one.

At the level of theory a first step towards the Romanisation of the feudal and customary laws was achieved through the notion of a 'common law' (ius commune), an expression to be found in the Roman sources. ${ }^{65}$ This medieval ius commune was based on the glosses and commentaries on the Roman and canon law sources and it was contrasted with the iura propria, the actual customary laws in force in the regions and villages. The relationship between the two was hierarchical; the ius commune provided the general theory for thinking about law and the methods of legal reasoning - and it would also fill any gaps in local

\footnotetext{
61 Ullmann (1975), at 111.

62 Comment on D.9.2.52.2. The expression is earlier used by Bartolus: comment on C.9.1.

63 Comment on D.1.1.

64 See Errera (2006), at 111.

65 See generally Maruotti (2011), at 65-69.
} 
laws - whereas the ius proprium could not inform the ius commune. ${ }^{66}$ What gave the ius commune its authority was the authority of the Roman and canonical texts themselves within a societas Christiana. This law was written and this in itself gave it a power over the largely non-written customs. Moreover, thanks to the work of the Glossators, the Roman and canon law had gained an intellectual authority (ratio scripta); it was a systematic (ratio) and logical law (principia) which stood in contrast to the 'deviant' customary rules. ${ }^{67}$ And so gradually the Roman model was able to penetrate into the iura propria, especially as the latter were not regarded as very relevant to the developing Italian city states. It was the Post-Glossators who provided the legal and political foundations for these urban centres. ${ }^{6}$

As for methodology, the Commentators continued and developed the dialectical methods - although not it has been argued at the expense of substance 69 - but at the same time they also displayed several marked shifts in the attitude to the Roman sources. ${ }^{70}$ First, as their name suggests, they moved away from glosses towards independent commentaries, sometimes long, on aspects of the law and, in doing this, they extended their interests beyond Roman law itself to embrace fully customary, municipal and canon law. Secondly, they took law out of the lecture hall - a process in fact begun by the Glossators - and into the contemporary legal context in which they were living. They did this partly through their commentaries (which for the most part were very practitioner orientated), but in particular through their practical opinions (consilia) on actual legal problems and issues. The Commentators were both teachers and practising lawyers - some even judges - and this is why their reasoning methods are important. Thirdly, they regarded Roman law as a toolbox consisting of useful material that could be adapted, through commentary, to the present necessities; they 'harmonized, or attempted to harmonize, law with the social and political realities' ${ }^{71}$ Fourthly, the Commentators took a more developed interest in interpretative methods and as a consequence laid the foundations for an increasingly sophisticated hermeneutical approach to law. ${ }^{72}$ Fifthly, as we

66 In a consilium Bartolus notes for example that one cannot normally derogate from the ius commune.

67 Maruotti (2011), at 67.

68 See eg Canning (1987).

69 Ullmann (1946), at 20.

70 See generally Carbasse (1998), at 144-150.

71 Ullmann (1946), at 4.

72 Maclean (1992), at 14. 
have seen, they began to lay the foundations for a science of law founded on immutable principles (principia) which acted as the universal premises for reasoning syllogistically. Instead of regarding the Roman regulae iuris as mere brocardia or summaries of the law they began to see them as the sources underpinning legal science itself (scientia iuris). Those who wish to know law must know its foundational principia.

The Glossators had of course been preoccupied with the definition of notions to be found in the Roman sources, but their interpretation of these terms tended towards literal precision, as one might expect given the task they were facing and the unfamiliarity of the material. ${ }^{73}$ The Commentators, in comparison, were operating in un deuxième temps in which it was no longer a question of explaining Roman law, but of 'appropriating' it and going beyond its surface meaning. ${ }^{74}$ This generated a dichotomy that was to act as the foundation for an increasing number of works on interpretation which in turn was stimulated by a title in the Digest devoted to the meaning of words. ${ }^{75}$ The dichotomy was that between what might be termed the surface meaning of words and their deeper 'force' (potestas: this idea of 'force' being found in the Roman sources): $;^{76}$ or, as the famous Post-Glossator Baldus put it, the distinction between ad literam and ad sensium. ${ }^{77}$

The dichotomy was important in terms not just of the dialectic itself, but of the interspace between the two which provided a very rich and fertile ground for generations of jurists from the Commentators onwards to develop hermeneutical method and philosophy within legal reasoning and argumentation. Ideas like mens (intention), intellectus (understanding) and ratio (reason, principle) became focal points for interpreting, applying and extending written laws through argumentation. Thus, said one Commentator, it was permissible to extend a law by way of analogy to a situation not directly covered by it if the ratio underlying the law would be applicable just as much to the new situation. ${ }^{78}$ The Commentators also spoke of an extensive (extensiva) and a restrictive (interpretatio declarativa, restictiva) interpretation of written laws; one must

\footnotetext{
73 Maruotti (2011), at 94.

74 Carbasse (1998), at 159.

75 D.50.16.

76 D.1.3.17: Scire leges non hoc est verba earum tenere, sed vim ac potestatem.

77 Maclean (1992), at 115; Baldus: interpretatio non debet fieri ad literam, sed ad sensium, quia sensus verborum praevalet (comment on C.6.28.3 no 1).

78 Ullmann (1946), at 117. Lucas de Penna: Ubi enim eadem vel major est ratio, trahitur lex ad casum simile etiam non expressum.
} 
try to discover whether the legislator was simply giving examples to illustrate a deeper ratio but, equally, one must avoid creating new law through interpretation. ${ }^{79}$ Notions such as intention (mens) and authority (auctoritas) (of the legislator) acted as a restraint on extensive interpretation. One might note, in addition, the importance of equity in the interpretation of law; ${ }^{80}$ it provided a counter-balance to the rigidity of the law and is rooted in every aspect of ius itself and of natural reason (naturalis ratio). ${ }^{81}$ Indeed it was said to be attached to every source and institution of the law ranging from the mind of the legislator (mens legislatoris) to the office of the judge. ${ }^{82}$

Dialectics (including Aristotelian logic) and hermeneutics were, then, two methods that were fundamental to the late medieval jurists' reasoning. However, they overlapped in as much as the use of distinctiones and divisio played an important part not just in interpretation itself but also in the fashioning of taxonomies of types of interpretation. Some of these distinctions were detailed and elaborate, ${ }^{83}$ but broadly speaking the Commentators identified four focal points of reasoning that could be brought to bear on the interpretation of legal texts. One could emphasise the intention of the legislator (mens legis), the significance of the words of the text (verba legis), the logic and coherence of the law (ratio legis) or the preference of equity to strict interpretation (ratio aequitatis). ${ }^{84} \mathrm{In}$ addition Donald Kelley reminds us that one must not forget the important role of other ideas such as cause (causa) and natural law (ius naturale) in the "hermeneutical process of "extension", 85

\subsection{IUS COMMUNE AND THE DEVELOPMENT OF METHOD}

By the end of the medieval period Roman law was being received into Europe rather than imposed as such. Clearly the feudal model often dominated as the immediate law in force - the ius proprium - but Roman

79 Ibid, at 117-118. Kelley (1990), at 133-134. Although Paulus de Castro said interpretatio facit ius (comment on D.1.3.9 no 4).

80 On which see Maruotti (2011), at 101-105. The basis is to be found in a Roman regula: D.50.17.90.

81 Maclean (1992), at 175; Ullmann (1946), at 41-44.

82 Maclean (1992), at 176-177.

83 Ibid, at $114-119$.

84 Ullmann (1946), at 119-122.

85 Kelley (1990), at 138-140. 
law acted as the foundation of a second level 'common law' (ius commune) which informed reasoning, interpretation and much conceptual analysis. The Corpus Iuris was une forteresse de mots, ${ }^{86}$ a 'toolbox', whose tools could be manipulated in all kinds of ways to construct a vision of both public and private society but which was beginning to be seen not as something 'static' and unchanging. Times had changed. The institutions and concepts of Roman law remained valid but their contents were modified by the social realities of the time with the result that the jurists were faced with having to transform a ius antiquum into a usus modernus. ${ }^{87}$ Kelley regards this process not so much as an epistemological phenomenon (episteme) but one of sagesse (phronesis); and while he is right to treat scientia iuris as a reasoning process that is different from reasoning in the natural sciences it nevertheless remains important not to lose from sight the epistemological assumptions that underpinned the approach of the Commentators.

One of these assumptions was the authority that attached to texts, to rulers and to God. Within the Roman texts there were fundamental notions such as justice (justitia), jurisdiction (jurisdictio) and natural law (ius naturale) capable of acting as the basis of theories about law, and the Post-Glossators, in their commentaries, started to develop sophisticated theories. However, they did not do this directly. Unlike modern jurists, the medieval jurists did not fashion theories in a top-down way; that is to say they were not conscious of being theorists as such. They operated in what might be termed a 'bottom-up' way in that their theories emerged often out of the way they solved practical questions or interpreted particular Roman texts. For example law was a matter of 'command addressed to everyone, issued by the competent authority and regulating social life by injunctions and prohibitions' ${ }^{88}$ As to the source of this power of command, there was an intense debate surrounding the Lex Regia which, according to a famous text in the Digest (D.1.4.1), was the means by which the Roman emperor (princeps) obtained his power and authority. The Roman people (populus) had originally transferred, via the lex, their power to the prince. As city states developed in medieval Italy questions arose as to whether they themselves could legislate or was the only source of this power to be found in the universal emperor of the Holy Roman Empire. Bartolus was not prepared to let go of the idea of a universal emperor (dominus mundi) but he equally recognised political

\footnotetext{
86 Carbasse (1998), at 159.

87 Kelley (1990), at 142.

88 Ullmann (1946), at 44.
} 
reality; many city states simply did not see themselves under such jurisdiction. So the question was this. Was the ultimate source of legal authority located in the princeps or in the populus? In recognising that the city state (civitas) could legislate he formulated the theory that the city was a corporation (universitas) whose populus was equally the princeps and thus it could pass such laws as it pleased. No doubt for Bartolus this was just a legal opinion aimed at solving a practical problem. But viewed from today's position, one can see that the jurist was equally laying down the legal foundation for a sophisticated political theory. As Thomas Hobbes was later to say: Civitas Persona una est. ${ }^{89}$

What is revealing about this and similar debates is the way that concepts and notions in the Roman texts - which of course had an absolute authority - could give rise to reasoning about political and social questions. ${ }^{90}$ The medieval jurists, operating within the context of societas Christiana, took legal reasoning and argumentation, with respect to the nature of law and its fundamental precepts such as equity, justice and power, well beyond anything achieved by the Roman lawyers. And in doing this they not only embedded the Roman concepts into the vocabulary of all thinking about law but gave these concepts a hugely rich set of dimensions. Notions such as proprietas, possessio, potestas, justitia, lex and ius acted as the means both of solving practical legal problems and of stimulating abstract theorisation about the nature of law and its role in society.

A dominating method, particularly for arriving at a solutio, was the dialectical technique of distinctions and division. ${ }^{91}$ Yet this technique, as Ian Maclean points out, was more than just hair-splitting; it was a heuristic tool by which the medieval jurists were able to grasp the 'infinite particulars of human life' ${ }^{92}$ Indeed it was more than just a heuristic tool 'since it deals with the necessary distinction between genera and species, whole and parts, various meanings of words, and accidents and subjects'. ${ }^{93}$ Moreover it permitted jurists to identify different kinds of hermeneutical approaches when faced with the meaning and signification of legal texts. ${ }^{94}$ As Carbasse observes, 'the clarity of

89 Hobbes (1668), ch XVII.

90 Ullmann (1946), at 35-61.

91 See eg the problem posed by Bartolus with regard to inheritance: Ullmann (1946), at 89 ('Bartolus proposed a distinction for the purpose of determining ...').

92 Maclean (1992), at 113.

93 Ibid, at 74.

94 Ibid, at $114-119$. 
the classifications constituted the foundation of the legal art' 95 and the importance of the Commentators is that they began to develop this art in a more systematic way, especially in the use of the two part dialectical plan employed when dealing with complicated questions of law. ${ }^{96}$ The divisions and subdivisions gave rise to a tree-like plan consisting of branches and sub-branches with the result that an area like procedure, the law of actions, was presented in terms of Arbores actionum. ${ }^{97}$ These arboreal 'systems' - which were first developed by the Glossators - were still tied to the internal ordering of the Corpus Iuris since it was the text and not the 'system' that provided the authority for any comment or opinion. ${ }^{98}$ But the 'tree' also offered a visual representation of the dialectical analysis in terms of alternative dichotomies.

Take an example from Roman law discussed in Gordley. ${ }^{99}$ Smoke from a cheese-maker's workshop invades the premises of a building above it and the question arises as to whether the occupier of the higher premises will have an action against the operator of the workshop. A text from the Roman jurist Ulpian, which reviews the writings of previous jurists, indicates that in the absence of a servitude there would be an action. The same would be true if water, from the higher building, invaded the lower building. ${ }^{100}$ In a text that immediately follows, a doubt is raised as to whether the position would be the same with respect to a moderate amount of smoke from, say, a domestic fire. ${ }^{101}$ Bartolus, commenting on this problem, brings to bear on this issue an 'either/or' dialectical analysis. First, either the occupier of the ground floor makes the smoke intentionally to cause damage to his neighbour or he does not do it intentionally. If he does it intentionally, then there will be liability. ${ }^{102}$ Secondly, either the occupier of the ground floor makes a moderate amount of smoke for family purposes or he makes an immoderate amount for work purposes. If the smoke is immoderate there will be

\footnotetext{
95 Carbasse (1998), at 160.

96 Ibid, at 161.

97 Ibid.

98 Robinson, Fergus and Gordon (2000), at 70. Even interpretation as an issue in itself was not subject to any independent monograph before the fifteenth century; commentaries are attached to various titles in the Digest which raise issues of interpretation such as D.1.3, D.50.16 and D.50.17: Maclean (1992), 83-85.

99 Gordley (2013), at 37-39.

100 D.8.5.8.5.

101 D.8.5.8.6.

102 See eg D.47.10.44.
} 
liability but, if not, there will be no liability. ${ }^{103}$ Now this is not a particularly complex example and one can certainly argue that this solution seems inherent in the Roman texts themselves, but the skill of a jurist like Bartolus was in the way his analysis brings the legal solution clearly into focus. This kind of algorithmic systema was both a method and a form of representing the law. And so by 'following up each alternative until the original alternatives had multiplied and ramified to become an analytical outline of all foreseeable cases, and at each step in the process citing an appropriate provision in the corpus of the ius commune', 104 the medieval jurists were gradually fashioning a framework for logical reasoning in law. One might note another difference between the Ulpian and the Bartolus analysis. The starting point for Ulpian is, on the whole, the availability, or non-availability, of an action (actio); it is the remedy that is the focal point. This is not the case with Bartolus. He talks about the lawfulness or unlawfulness of the situation.

This said, it must be stressed that this framework was not yet fully deductive in its orientation. It was not a matter of starting out from a general rule (regula) and, through the Aristotelian syllogism (known of course to the medieval jurists and philosophers from the middle of the twelfth century), arriving at an inferred conclusion. As Gordley notes, 'the medieval jurists sought order by linking one Roman text to another' whereas modern jurists 'explain rules by means of higher-level rules and concepts'. ${ }^{105}$ This is a particularly valuable insight. Yet there was a type of logic in operation of the dialectical kind: either A or B, if not A, then B. This is summed up in the famous adage from the Gospel, actually quoted by Bartolus, 'who is not with me is against me'. ${ }^{106}$

As for general rules (regulae, praeceptae), these seemed not to have acquired a complete authority in their own right divorced from the legal texts, ${ }^{107}$ although they may have gained a 'truth' value if they had the support of the majority of the doctors (communis opinio doctorum). ${ }^{108}$ They were the product of induction from particular cases and so the primary method was reasoning from the particular to the particular; that

\footnotetext{
103 Bartolus, Commentaria, D.8.5.8.5 cited in Gordley (2013), at 38.

104 Bellomo (1995), at 183.

105 Gordley (2013), at 51.

106 See Bartolus' comment on C.1.9.9 no 1: Qui non est mecum, contra me est.

107 Bellomo (1995), at 188.

108 Maclean (1992), at 76.
} 
is to say reasoning by way of analogy. ${ }^{109}$ Thus the Commentators would fill gaps by a mixture of both textual authority and analogy; if there was a problem about lemons but no text concerning lemons, then, if there was a text concerning oranges, the jurist would transfer this oranges rule to the problem of lemons. ${ }^{110}$ Accordingly 'by taking an existent disposition and using it as an indisputable base on which to construct a dialectical argument, the jurist expanded the normative capacities of Justinian's laws.' ${ }^{111}$ Nevertheless the Post-Glossators were beginning to see that beneath such analogies there existed a principium. As Baldus observed: Inductio, quae habet rationem, ad simile casu trahitur (induction, for anyone who thinks rationally, is about extracting [a principle] from similar cases). ${ }^{112}$ And before this comment he had also asserted that qui non intelligit principium casus, non potest intelligere casum (one who does not understand the principle behind a case is unable to understand the case). ${ }^{113}$

It is important to appreciate the methodology in play in this process. As a form of legal education this kind of dialectical reasoning and argument would take place within the formal procedure of the quaestio disputata where each argument had to be advanced in a particular way (pro and con) and had to be linked to a legal text acting as authority. ${ }^{114}$ There was, in other words, an auctoritas that attached both to the form and to the substance of this whole legal reasoning process. This authority had the effect both of consolidating and of limiting within defined boundaries the reasoning methods of the civilian jurists. 'Hidden in the glosses, commentaries and lexica', observes Ian Maclean, 'is a tacitly agreed agenda of analysis' in which 'conservative forces were at work to preserve technical vocabulary and the terms of the debate from change; and that the realm of law and legal interpretation operated as a coherent and recognizable practice'. ${ }^{115}$

109 Maclean (1992), at 79-80 (procedendum est de similibus a similia). See eg Philippus Decius' comment on C.6.10 Lex 2 No 20 (In Digestum Vetus et Codicis Commentarii). Regulae iuris are to be found in cases and emerge ex post facto.

110 For examples see Bellomo (1995), at 182-183.

111 Ibid, at 183.

112 Comment on D.1.3.13 Additio.

113 Comment on D.1.2.1 no 12.

114 Ibid, at 185.

115 Maclean (1992), at 40. 